\title{
J. W. GOETHE AND THE BALTICS Introductory remarks
}

On a wet and foggy October day the noble anniversary of Johann Wolfgang von Goethe has finally arrived to Riga, to Latvia, to the Baltic countries. Today the scientific part of the anniversary symposium "Goethe and the Baltics" is starting. Allow me to congratulate in the name of Latvia's Academy of Sciences the members and organisers of the symposium, the Institute of Goethe, the Institute of Literature, art and folklore, the Goethe Society, Dr. Gundega Grīnuma and, last but not least, Ojārs Zanders, whose erudition and industriousness has managed to organise an exhibition of cultural and historical value on Goethe and Latvia. I regret not being able to congratulate you yesterday because of an important Science council meeting with voting and this was followed by a grand international conference "The Jews in a changing world" which was organised by the LAS.

Gundega Grīnuma asked me to express some opinions on Goethe, the Baltic countries and this symposium. They will, of course, be quite subjective, even trivial. As to my mind, in contrast of Kant and Herder, the region, which we now call the Baltics, seemed to Goethe as being of a distant periphery. Goethe's connections with the Baltics were of a marginal character. That is why this symposium will not voice anything new concerning Goethe himself and his problems, although the reporters will surely give some new and intriguing facts, of some unexpected aspect. However, the essentials will concern Goethe's reception in the Baltics, on his influence here. This reception has to my mind followed on two levels. One has influenced the upper layer of the German society, the Baltic nobles and literary representatives; this was earlier and more direct; the second influence was on the basic nations - the Latvians, Estonians and Lithuanians; this came later, but was probably even deeper and more constant, and historically more significant.

* Address to the international interdisciplinary symposium "Goethe and the Baltics", Riga, Goethe Institute, 1999, $28^{\text {th }}$ October. 
When mentioning the first aspect the most important persons in Goethe's biography should be mentioned - Herder, Reinhold Lenz, Garlieb Merkel, Elisa von Recke as well as the Latvian cultural worker in Germany Konstantin Kraukling. One cannot assert that Goethe's attitude towards these persons was always harmonious; we know how strained his relationship was with Merkel, Klinger and Lenz; even with Herder they were contradictory. Of special gratification is the fact that the conference will widely reflect the theme "Goethe and the Natural Sciences ", which includes Goethe's activities in anatomy, the theory of light, the numerous scientists around Goethe. Here one should mention the various activities with the University of Jena (whose professor was Friedrich Schiller) - it was here that Merkel studied, as well as the first Latvian natural scientist, doctor and pharmacist David Hieronimus Grindel.

However, above all, one should mention professor of anatomy Justus Christian Loder, who was born in Riga as the son of the director of a Riga lyceum. Loder was teacher of Goethe in anatomy under whose guidance Goethe performed his anatomical studies. One should mention that Loder was the theme of dissertation for obtaining the degree of doctor at the Free University of Berlin, which was successfully defended by director of the Institute for History of Medicine Juris Salaks. He will report his research at the conference.

I would like to mention in this context the outstanding Baltic natural scientist chemist and physicist Theodor Grothus, who performed his research on light about the same time as Goethe, only viewing it from another angle ignoring Goethe's teaching about colours. Thus Goethe had friends, admirers in the Baltics as well as radical opponents; this state of affairs is of credit to the Baltics proving that it was not a mere provincial region. I should like to mention that unfortunately Goethe was not elected as honorary member of our first Literary and Art Society in Courland - our first Academy of science.

However, more important - not only in the perspective of time - was the second reception on Goethe in the Baltics - among the culture of the native inhabitants. This reception should be connected with the thesis "Goethe - the European"; it must be connected with the Europisation of the Baltic peoples. It was during Goethe's life - which was also the time of Alexander I and the Napoleonic wars - that early Baltic modernisation began; serfdom was abolished first in Estonia, then in Kurzeme and Vidzeme; Latvian secular literature appeared, at first under the auspices of German priests; let us remember the Stenders, Stobbe, Hugenberger, Elverfeld, Lundberg, as well as the somewhat weak original literature in the works of Blind Indrikis.

Latvians might have been influenced by Schiller before Goethe, for his work "The Robbers" was translated and acted in Dikli about 1818. This is one of the firsts if not the first play acted in Latvian. While investigating the activities of young Stender after his father's death in Sunākste, I found that he had localised "Gaudeamus igitur" (Brethren, let us be merry) in Latvian. He had 
also translated Schiller's "Ode to Merriment", the present hymn of the European Union. This all happened when the greatest part of Latvians were still serfs. Thus Europeisation of Latvians had begun, while they were still living in serfdom and that was the time when the first translations of Goethe might have appeared. The translator Carl Hugenberger later the priest of Ārlavas parish and the Head of the Society of Latvian friends, "the grey haired friend of Latvians" as he used to call himself, had studied in Jena from 1801-1804 medicine and theology. From there he had visited Weimar, where Schiller and Goethe directly influenced us. Reception of German culture in Latvia took place earlier than that of the Russian culture, which, in fact, began with the "new Latvians". That was thanks to the Baltic German clergymen.

To tell the truth, Goethes reception by Latvians, started with Juris Alunāns "Little Songs". Then follow Rainis and Aspazija; Goethe has had a very strong influence on Poruk's literary art and all the rest which has been widely discussed at the Goethe symposium in 1997 that is going to be reported today. Like other European cultures Goethe has also enriched the Latvians. We are proud of that. We honour Goethe also because of the new translation of "Faust" by V. Bisenieks and the rockopera "Faust". This is proof of the manifold influence of Goethe upon Latvian cultural philosophy, the theatre and opera.

Though speaking about Goethe today, we cannot avoid one aspect. Without doubt one could say that Goethe was the first German European; today in Eastern Europe there is much talk about our entering Europe, although we have been there undoubtedly already since Goethe's time. Here we could ponder where we would like to enter - in the economy of Europe, in the bureaucratic Europe of Brussels, in the political Europe or the Europe of culture. These days we definitely vote for the "cultural Europe" although there remains one problem - will this Europe, even in a gentle way, not rob the small nations of their value and identity?

In this connection I would recall an episode connected with Latvian cultural philosophers Zenta Maurina and Konstantins Raudive, whom I slightly remember from my early childhood, when my father doctored Zenta Maurina and whose talks I was able to hear; at that time the same problem was tackled. This episode was later described in the autobiographical trilogy in the third book "Iron bolts are falling ". I would like to quote its essence.

"Albatross (i.e. Raudive - J. S.) regarded Goethe as the symbol of spirit. He had planned to publish selected works by Goethe in 10 volumes in Rasins publishing house. 20 translators had already been selected. We regarded this enterprise as beneficial, for Goethe belonged to the inventory of Latvia's culture and was above parties, wars, and peace, above nationalism and bolshevism. Which cultural level of a people could be determined by the chronology of Goethe's translations and interpretations? Among the three 
Baltic nations Latvians have the oldest traditions of Goethe. Only the first part of "Faust" has been translated into Lithuanian, besides 37 years later than in Latvian. The attitude of our people towards Goethe proves that we belong to Western Europe. Even our own beloved works of our classics have not been published in more copies. The author handed in the plan of the articles to the Ministry of Propaganda, in order to obtain permission to publish it. The answer was shattering. The publication of Goethe's works in Latvian was strictly forbidden. The Latvians were said to be a peasant folk who did not need Goethe. If there were individuals who were developed enough to read Goethe, they could surely do it in German".

Maurina's book describes this episode on a wider scale, on several pages; she relates her talk with the censor, his contemptuous evaluation of a puny people and their right to independence; a two year old struggle is described, so that Rasiņš publishers could receive permission to publish Goethes writings in Latvian; only the first volume managed to appear. I remember from my childhood holding this volume in blue covers which after a period of three years I presented to my class mistress when finishing elementary school.

Why do I reminisce about this sad episode in the day of Goethe's glory, the glory of the German people, Europe's glory? The gloomy time of Hitler's occupation has passed long ago, the past also belongs to the "New Europe" which a Hitler clerk could arrogantly explain to Zenta Maurina that Herder's and Hegel's errors had been corrected by another higher " $H$ " - Adolf Hitler. However the new Europe which is at present developing is based on quite different principles than Hitler's imagined "New Europe". That could rather be Goethe's "New Europe".

Small nations, however, must always be alert about their national identity and their rights to exist. This means to exist and be open to positive, developing impulses. That is what was being discussed dramatically at the conference devoted to the $100^{\text {th }}$ anniversary of the outstanding philosopher, sociologist and politician Jesay Berlin.

This week is in general significant for Latvia. The time of souls of the dead is approaching and with it a time of reminiscence. Yesterday we opened a memorial plaque to Alexander Pushkin thus closing the UNESCO supported $200^{\text {th }}$ anniversary. Not regarding rain in the overcrowded "Ave Sol" hall many people who were craving for culture had gathered. Yesterday, at an international Conference "Jews in a changing world" we were honouring the Riga born Jesay Berlin and his $100^{\text {th }}$ anniversary who was the ideologist of Europe's freedom and liberalism. We recalled that his name is one of those names from the Baltic which is inscribed in the "Hall of Liberty" in Switzerland, at the peak of the Jungfrau next to Jānis Čakste and Jan Tõnison. Goethe is not included in this list. 
At the end of this week we shall burry in Nereta Kesteri cemetery the ashes of Latvian poetess Velta Toma who died in Canada. And, of course, " prima pars" follows the paying of homage to Goethe in Latvia, which uplifts us and brings nearer to the highest values, which have been created by humanity. We offer our thanks to Goethe Institute and the Goethe Society for this grand homage to the European Olympian in Riga. It is Goethe, his ideas, and his heritage that could be a firm ground for our integration into Europe. I wish that this symposium should not be embodied only in speeches, reports, and exhibitions, but should also be materialised in a book with the ideas expressed here.

Maybe the words by Zenta Mauriņa may sound old fashioned and rhetorical, however, I want to remind you of them today: "Tell me what you think about Goethe, and I will tell you who you are". Many people, even too many of them do not think anything about Goethe at all and they are still very honoured men this is the truth and characteristic of this age.

Jānis Stradiň̌, Dr. hist. h.c. Professor, President of Latvia's Academy of Science Akadēmijas lauk. 1, LV 1524, Rīga, Latvia

E-mail: stradins@ac.lza.lv 


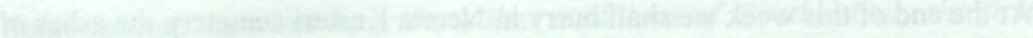

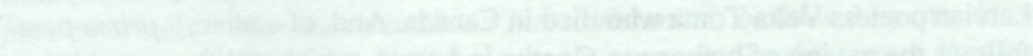

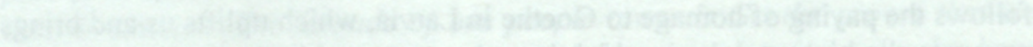

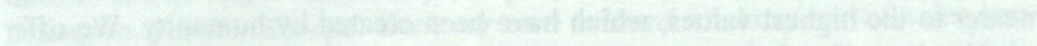

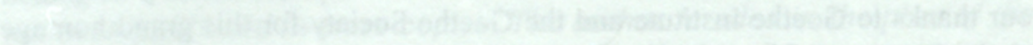

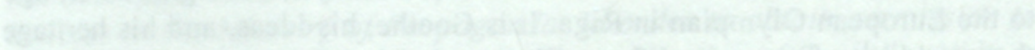

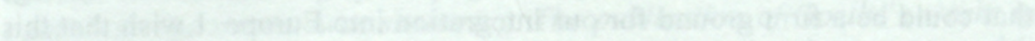

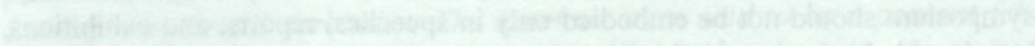

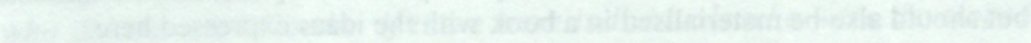

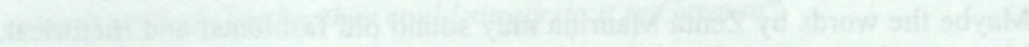

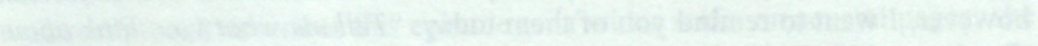

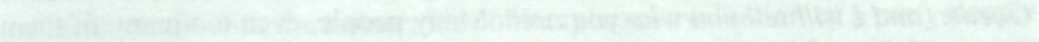

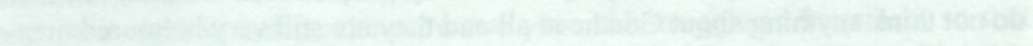

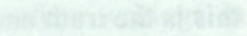

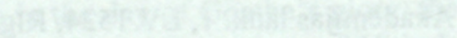

